\title{
Root foraging and avoidance in hyperaccumulator and excluder plants: a rhizotron experiment
}

\author{
Alice Tognacchini • Mirko Salinitro • Markus \\ Puschenreiter • Antony van der Ent
}

Received: 1 October 2019 / Accepted: 6 March 2020 / Published online: 8 April 2020

(C) The Author(s) 2020

\begin{abstract}
Aims Metal hyperaccumulation is a rare phenomenon described for an increasing number of plant taxa. In this study we investigated the root growth responses of the well-known nickel, zinc, cadmium hyperaccumulator Noccaea caerulescens and of the metal tolerant (nonaccumulator) Stellaria media, in order to observe root foraging vs avoidance responses to nickel.

Methods To allow for observations of root growth and foraging preferences, two accessions of Noccaea caerulescens and two accessions of Stellaria media orginating from high nickel and low nickel habitats were grown in rhizotrons with localized nickel enrichment. Results The root density in the control and nickelenriched soil areas in the rhizotrons with different
\end{abstract}

Responsible Editor: Juan Barcelo.

A. Tognacchini $(\bowtie) \cdot$ M. Puschenreiter

Department of Forest and Soil Sciences, Institute of Soil Research, University of Natural Resources and Life Sciences, Vienna,

Austria

e-mail: alice.tognacchini@boku.ac.at

M. Salinitro

Department of Biological, Geological and Environmental

Sciences, University of Bologna, Bologna, Italy
$N$. caerulescens accessions had distinct responses: moderate nickel avoidance was recorded for the non-nickel accession, while a clear foraging response was observed in $N$. caerulescens from the nickel accession. In contrast, nickel rooting avoidance was observed for both $S$. media accessions and was more pronounced in the non-nickel accession.

Conclusions This study shows that $N$. caerulescens originating from different accessions responded differently to soil nickel enrichment, with the nickel accession of $N$. caerulescens actively foraging for nickel, suggesting a physiological adaptation and demand for this metal. In contrast, a clear nickel avoidance response by a metal tolerant species, $S$. media, was observed in this study, a phenomenon which has not been previously

\footnotetext{
A. van der Ent

Centre for Mined Land Rehabilitation, Sustainable Minerals Institute, The University of Queensland, Brisbane, Australia

A. van der Ent

Laboratoire Sols et Environnement, Université de Lorraine INRA, UMR 1120 Nancy, France
} 
described; this suggests that root avoidance responses might play a role in the adaptation of metal tolerant species to Ni-rich soils.

Keywords Nickel · Hyperaccumulation · Metal tolerance $\cdot$ Root foraging $\cdot$ Root avoidance

\section{Introduction}

Plants colonizing metalliferous soils ('metallophytes') have evolved physiological mechanisms which enable them to tolerate metal toxicity at the plant level (Baker 1981). These mechanisms to cope with extremely large (toxic) metal concentrations in their growth medium can be classed in three categories: (i) excluders (ii) indicators and (iii) (hyper) accumulators (Baker 1981). In excluder plants, metal concentrations in the shoot are maintained constant and low over a wide range of soil metal concentration gradients (Baker 1981). Conversely, metal hyperaccumulators are able to accumulate extraordinarily high concentrations of specific metals or metalloids into their shoots (Baker and Brooks 1989; Reeves and Baker 2000; van der Ent et al. 2013). Hyperaccumulator plants can achieve such extreme levels of foliar sequestration due to enhanced uptake and translocation mechanisms (Baker 1981, 1987); with threshold levels of $1000 \mu \mathrm{g} \mathrm{g}^{-1}$ for nickel (Ni), $300 \mu \mathrm{g} \mathrm{g}^{-1}$ for cobalt (Co), $3000 \mu \mathrm{g} \mathrm{g}^{-1}$ for zinc ( $\mathrm{Zn}$ ) and $10,000 \mu \mathrm{g} \mathrm{g}^{-1}$ dry weight for manganese $(\mathrm{Mn})$ (Baker and Brooks 1989; van der Ent et al. 2013). Metal hyperaccumulator plants have received more attention than metal excluders due to their potential for applications in the remediation of metalcontaminated soils (Baker et al. 1994; Lombi et al. 2000; Krämer 2005; Wenzel et al. 1999). Among the over 700 metal hyperaccumulator plants currently known (Baker and Brooks 1989; van der Ent et al. 2013), most research to date has focused on small biennial or short-lived perennial European species that have a large natural variation for trace metal hyperaccumulation, specifically: Noccaea (synonym Thlaspi) caerulescens (J.Presl \& C.Presl) F.K.Mey. (Gonneau et al. 2014; Schwartz et al. 2006) and Arabidopsis halleri (L.) O'Kane \& Al-Shehbaz. (Verbruggen et al. 2009, 2013; Krämer 2010; Hanikenne and Nouet 2011; Meyer et al. 2015). Despite being an uncommon species, $N$. caerulescens can be found over a widespread area of central Europe, ranging from Poland and the Czech Republic in the east, west to Great Britain and south to northern Spain, and to the Alps on the border of France and Italy (Reeves et al. 2001). A peculiarity of this species is its occurrence on a variety of different substrates, ranging from uncontaminated "normal" soils to soils naturally enriched or contaminated soils with high concentrations of certain trace metals such as $\mathrm{Ni}, \mathrm{Zn}$ and $\mathrm{Cd}$. Even if occurring on uncontaminated soils, many populations of $N$. caerulescens can tolerate conditions on sites with anthropogenic metal pollution (Baker et al. 1994; Ingrouille and Smirnoff 1986; Gonneau et al. 2017; Meerts and Isacker 1997), including mine waste and smelter sites (Reeves et al. 2001); while other populations occur on Ni-rich soils developed from ultramafic bedrocks in Europe (Meyer 2006; Reeves et al. 2001; Sterckeman et al. 2017).

Following its adaptation spectrum, $N$. caerulescens is a Ni hyperaccumulator in ultramafic accessions, but can also be a Zn (Baker and Brooks 1989) and Cd (Brown et al. 1995; Hutchinson et al. 2000) hyperaccumulator when growing on $\mathrm{Zn}-\mathrm{Cd}-\mathrm{Pb}$ natural ('calamine') mineralised outcrops or contaminated sites (Assunção et al. 2003a; Callahan et al. 2016; Escarré et al. 2013; Gonneau et al. 2014; Peer et al. 2003). This ability to tolerate and accumulate several different metals likely reflects the relatively low specificity of some mechanisms involved in metal transport and chelation in this species (Merlot et al. 2018) and suggests that highly efficient mechanisms of foraging and uptake of these metals may be involved (Haines 2002). Despite the contribution of recent studies to elucidate plant-internal processes associated with metal hyperaccumulation (Assunção et al. 2003b; Brooks 1998; Krämer et al. 1996, 1997, 2000; Krämer 2010; Lombi et al. 2000), increased knowledge about rhizosphere processes (Dessureault-Rompré et al. 2010; Wenzel et al. 1999, 2003), the precise mechanisms by which hyperaccumulator plants take up metals from the soil is still relatively limited. Being a hyperaccumulator of different metals $(\mathrm{Ni}, \mathrm{Zn}, \mathrm{Cd}), N$. caerulescens is receiving considerable scientific attention with the recognition of its usefulness in ecological, physiological and genetics and molecular biological studies of metal accumulation (Baker et al. 1994; Craciun et al. 2012; Halimaa et al. 2014; Lasat et al. 1996; Milner and Kochian 2008; Milner et al. 2012; Puschenreiter et al. 
2003; Vàzquez et al. 1992), and the key role of metalaccumulating plants in remediating metal-contaminated soils using phytotechnologies (Baker et al. 1991; Brown et al. 1994; Escarré et al. 2000; Hammer and Keller 2003; Jacobs et al. 2017, 2018; McGrath et al. 1993, 2006; Robinson et al. 1998; Schwartz et al. 2003).

Understanding root responses is essential to improve knowledge of the physiological processes responsable for hyperaccumulation. The capacity of roots for differential growth towards various microenvironments has been shown for a range of different plant species (Haines 2002), but is one of the least well understood facets of plant life (Robinson 1994). Plants tend to concentrate roots (e.g. forage) in soil patches in which resources are more abundant (Fitter 1994), and proliferate lateral roots preferentially in nutrient-rich zones to access nutrients in diverse soil microenvironments (Guan et al. 2014). Thus, the major function of root foraging responses in higher plants is to explore and access essential resources, such as nutrients and water, that contribute to plant growth and development (Casper and Jackson 1997; Hodge 2004; Hutchings and de Kroon 1994; Liu et al. 2010; Robinson 1994; Schenk et al. 1999). Interestingly, root foraging responses were also reported for hyperaccumulator plants in the presence of certain trace metals such as Zn, Cd and Ni (Haines 2002; Liu et al. 2010; Schwartz et al. 1999; Whiting et al. 2000; Dechamps et al. 2008), suggesting that hyperaccumulator plants might have a specific requirement for these metals. Localized root proliferation (root foraging) is also listed as one of the most likely adaptations explaining the highly efficient metal uptake in N. caerulescens (Haines 2002; Schwartz et al. 1999; Whiting et al. 2000). Most experiments of root responses in relation to spatially localized resources in soil have so far concentrated on nutrients such a $\mathrm{NO}_{3}{ }^{-}, \mathrm{NH}_{4}{ }^{+}, \mathrm{P}$ and $\mathrm{K}$ (Hodge 2004; Guan et al. 2014; Robinson 1994), with only a few studies focussing on trace metals such as Zn (Haines 2002; Schwartz et al. 1999; Whiting et al. 2000; Dechamps et al. 2008; Saison et al. 2004), Cd (Liu et al. 2010; Schwartz et al. 2003; Whiting et al. 2000) and Ni (Dechamps et al. 2008). Previous studies on root foraging conducted with $N$. caerulescens have investigated the $\mathrm{Zn}$ foraging responses of this species, and positive root proliferation has been observed in response to substrate patches with high $\mathrm{Zn}$ concentrations (Dechamps et al. 2008; Schwartz et al. 1999; Whiting et al. 2000). Root responses of hyperaccumulator plant species in the presence of localized Ni enrichments were investigated in detail by Dechamps et al. (2008), where preferential root allocation on $\mathrm{Ni}$-enriched soil compartments was observed in a calamine $N$. caerulescens accession. Furthermore, Moradi et al. (2009) studied Ni foraging responses in the $\mathrm{Ni}$ hyperaccumulator species Berkheya coddii, without observing any preferential root allocation in response to soil $\mathrm{Ni}$. To the best of our knowledge, root responses of excluder plants to $\mathrm{Ni}$ have not been previously investigated.

The aims of this study were to address the following questions: i) Does the Ni hyperaccumulator $N$. caerulescens preferentially forage in $\mathrm{Ni}$-enriched zones? ii) Does a positive root response to $\mathrm{Ni}$ enhance metal accumulation in $N$. caerulescens? iii) Do excluder species have different root responses to Ni soil enrichment compared to hyperaccumulators? iv) Do different accessions of the same plant species respond differently to the presence of $\mathrm{Ni}$ in the soil? In order to address these questions, we have investigated the root responses of $N$. caerulescens in establish active Ni foraging vs avoidance strategies. The metal tolerant Stellaria media (L.) Vill. (Caryophyllaceae) was included in this experiment, to compare the root responses of $N$. caerulescens to a $\mathrm{Ni}$ excluder (non-accumulator) species. In order to allow for observations of root growth and foraging preferences, the tested plants were grown in rhizotrons with localized Ni enrichments. Nickel and non-Ni accession of each plant species were investigated to conduct comparative studies in terms of their relative root foraging responses.

\section{Methods}

Plant species

The Ni, Zn and Cd hyperaccumulator $N$. caerulescens and the metal tolerant (but excluder) species Stellaria media were selected for the experiment. Two accessions of each species, adapted to either high Ni or low Ni soils were used in the experiments . The high $\mathrm{Ni}$ accession of $N$. caerulescens was obtained from an ultramafic outcrop near Bergenbach, France (47 54'26'N 6 $\left.6^{\circ} 57^{\prime} 35^{\prime \prime} \mathrm{E}\right)$ (Chardot et al. 2007; Escarré et al. 2013; Reeves et al. 2001). Reported total near surface soil Ni concentrations in this site are in the range of 469 to $1301 \mathrm{mg} \mathrm{kg}^{-1}$ (Reeves et al. 2001) and up to $2500 \mathrm{mg} \mathrm{kg}^{-1}$ in the lower 
soil horizons (Chardot et al. 2007). The low Ni accession of $N$. caerulescens was obtained from the old $\mathrm{Zn}$ $\mathrm{Pb}$ mine of Plombieres, Belgium (50 44'04'N 5 57'53" E), a calamine site which has long been known for its remarkable metal-tolerant flora (Meerts and Isacker 1997; Simon 1975) and where N. caerulescens is a $\mathrm{Zn}$ hyperaccumulator. Accessions of $S$. media were obtained from the Ni-rich ultramafic area of Monte Prinzera (Italy, $44^{\circ} 38^{\prime} 25.2^{\prime \prime} \mathrm{N} 10^{\circ} 05^{\prime} 32.5^{\prime \prime} \mathrm{E}$ ), a site with a Ni total concentration of $2466 \mathrm{mg} \mathrm{kg}^{-1}$ (Lombini et al. 1998), as well as from the non-metalliferous site of Ticino

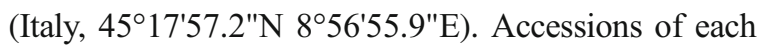
species were obtained from seed material collected in the field from different plant individuals.

\section{Experimental setup}

\section{Soil preparation and analyses}

A garden soil characterized by low total and plant available Ni concentrations was selected for the experiment (Table 1). The selected soil had relatively high $\mathrm{Zn}$ concentrations (Table 1 ) which is particularly advantageous as $N$. caerulescens has a high constitutive requirement for $\mathrm{Zn}$ and a greater sensitivity to $\mathrm{Zn}$ deficiency than non-accumulator plants (McGrath et al. 1997; Ozturk et al. 2003; Shen et al. 1997); and this experiment aimed

Table 1 Pseudo-total, DTPA-extractable element concentrations, $\mathrm{pH}$, Olsen-P, TOC, TN and texture of the control and Ni-spiked (garnierite and Ni-carbonate) soils

\begin{tabular}{llccc}
\hline & & Control soil & Garnierite & Ni-carbonate \\
\hline $\mathrm{Ca}_{\text {total }}$ & $\mathrm{g} \mathrm{kg}^{-1}$ & $6.91 \pm 2.5$ & - & - \\
$\mathrm{Mg}_{\text {totoal }}$ & $g \mathrm{~kg}^{-1}$ & $1.76 \pm 1.6$ & - & - \\
$\mathrm{K}_{\text {total }}$ & $g \mathrm{~kg}^{-1}$ & $3.04 \pm 1.1$ & - & - \\
$\mathrm{Fe}_{\text {total }}$ & $\mathrm{g} \mathrm{kg}^{-1}$ & $24.3 \pm 1.6$ & - & - \\
$\mathrm{Mn}_{\text {total }}$ & $m g \mathrm{~kg}^{-1}$ & $194 \pm 2.7$ & - & - \\
$\mathrm{Zn}_{\text {total }}$ & $m g \mathrm{~kg}^{-1}$ & $422 \pm 0.8$ & - & - \\
$\mathrm{Zn}_{\mathrm{DTPA}}$ & $m g \mathrm{~kg}^{-1}$ & $100 \pm 3.1$ & - & - \\
$\mathrm{Ni}_{\text {Total }}$ & $m g \mathrm{~kg}^{-1}$ & $9.36 \pm 21$ & $1987 \pm 15$ & $2006 \pm 3.1$ \\
$\mathrm{Ni}_{\mathrm{DTPA}}$ & $m g \mathrm{~kg}^{-1}$ & $0.454 \pm 8.9$ & $3.63 \pm 0.6$ & $984 \pm 1.0$ \\
$\mathrm{Olsen}-\mathrm{P}$ & $m g \mathrm{~kg}^{-1}$ & $49.3 \pm 3.3$ & - & - \\
$\mathrm{pH}$ & & $6.98 \pm 0.1$ & $7.01 \pm 0.1$ & $7.43 \pm 0.1$ \\
$\mathrm{TOC}$ & $\mathbf{w t \%}$ & $8.71 \pm 1.8$ & - & - \\
$\mathrm{TN}$ & $\mathbf{w t \%}$ & $0.50 \pm 3.4$ & - & - \\
Texture & & Sandy loam & &
\end{tabular}

Data show average values \pm relative standard deviation $\%(n=3)$ to reveal root responses to $\mathrm{Ni}$ while $\mathrm{Zn}$ supply is not limiting. A further selection criterion for the soil was its dark colour, in order to facilitate imaging analyses of root distribution based on colour contrast of roots/ background (see "Root density analyses" section). The soil was oven dried at $40{ }^{\circ} \mathrm{C}$ for $24 \mathrm{~h}$, sieved at $<1 \mathrm{~mm}$ and divided in equal parts of $1.5 \mathrm{~kg}$. Two aliquots of soil were enriched with $\mathrm{Ni}$, each with a specific $\mathrm{Ni}$ form and the remaining soil was kept as a control. Two Ni forms with low solubility were chosen for the soil enrichment, in order to avoid substantial Ni diffusion in the control soil: i) a pure natural garnierite mineral $\left((\mathrm{Ni}, \mathrm{Mg})_{3}\left(\mathrm{Si}_{2} \mathrm{O}_{5}\right)(\mathrm{OH})_{4} ; 20 \% \mathrm{Ni}\right)$ obtained from New Caledonia, ground and sieved to $<0.5 \mathrm{~mm}$ and ii) $\mathrm{Ni}$ carbonate chemical $\left(\mathrm{Ni}_{4} \mathrm{CO}_{3}(\mathrm{OH})_{6}\left(\mathrm{H}_{2} \mathrm{O}\right)_{4}, 99.9 \%\right.$, Sigma-Aldrich). An amount of each $\mathrm{Ni}$ compound was added to the soil in order to obtain a nominal Ni concentration of $2000 \mathrm{mg} \mathrm{kg}^{-1}$ to resemble typical total $\mathrm{Ni}$ concentrations of natural ultramafic soils. Moist soil was autoclaved, mixed with the $\mathrm{Ni}$ forms and manually homogenized, then oven dried at $40{ }^{\circ} \mathrm{C}$, re-moistened and re-dried along 10 days to allow equilibration. Half of the untreated soil to be used as control was limed with $0.2 \% \mathrm{w} / \mathrm{w} \mathrm{CaCO}_{3}$ in order to obtain the same $\mathrm{pH}$ as in the soil spiked with $\mathrm{Ni}$ carbonate, to avoid interference of other factors such as differences in nutrient availability among control and Ni carbonate spiked soil driven by different $\mathrm{pH}$ values. Soil $\mathrm{pH}$ was measured with a $\mathrm{pH}$-meter after mixing soil with ultra-pure water with a $1: 2.5$ ratio $w / v$ and performed in two replicates. Texture was measured following the wet sieving sedimentation method. Soil TOC and TN content were measured via combustion analyses (Dumas method) with a Vario Macro Cube instrument (Elementar). Available phosphorous was determined according to the Olsen-P method (Olsen et al. 1954) followed by molybdate blue colorimetry (Murphy and Riley 1962). A subsample of the control soil as well as the limed and Ni spiked soils were digested in $\mathrm{HCl} 37 \%$ and $\mathrm{HNO}_{3} 65 \%$ at $1: 3$ ratio (aqua regia) in a digestion block at $155{ }^{\circ} \mathrm{C}$ for $3 \mathrm{~h}$ to determine pseudo-total element concentrations. Plant available metal fractions were determined through DTPA (diethylene triamine pentaacetic acid) (Lindsay and Norvell 1978) extractions. Digested samples were measured for macronutrients with ICP-OES (Optima 8300, Perkin Elmer) and for trace metals with ICP-MS (Elan 9000 DRCe, Perkin Elmer). DTPA extracts were measured with ICP-MS (Elan 9000 DRCe, Perkin Elmer). 


\section{Rhizotron setup}

In order to observe root growth responses of the tested plant species in the presence or absence of $\mathrm{Ni}$, a rhizotron experiment was conducted. Rhizotrons consist of boxes with a transparent window filled with soil, which allow for non-destructive observations of roots on a transparent surface (Smit et al. 2000). Among the various types of methods described for investigating localized supply of nutrients or other elements, Robinson (1994) defined as ideal a system where no physical barriers are imposed to root growth. Therefore, we have chosen to setup a rhizotron experiment growing the tested plants on a substrate without any physical barrier between the control soil and the Ni enriched soil. Selfmade rhizotrons (Fig. 1) were constructed from Petri dishes $(12 \times 12 \mathrm{~cm})$, which were filled in with paraffine in order to reduce their thickness to $0.5 \mathrm{~cm}$. Openings for the seedlings transplantation and for watering were created on the upper part of the Petri dishes. In order to fill in the rhizotrons with a control soil (left side) and the $\mathrm{Ni}$ enriched soil (right side as in Whiting et al. 2000), a plastic foil was used to create a vertical separation, which was subsequently removed. Limed soil was used as a control for the Ni carbonate treatments. The soil surface on the whole rhizotrons was then carefully compacted to avoid inhomogeneities to appear during the plant growth, as well as to allow for precise root observations. Seedlings were prepared on a vermiculite and quartz sand mix and transplanted into the rhizotrons

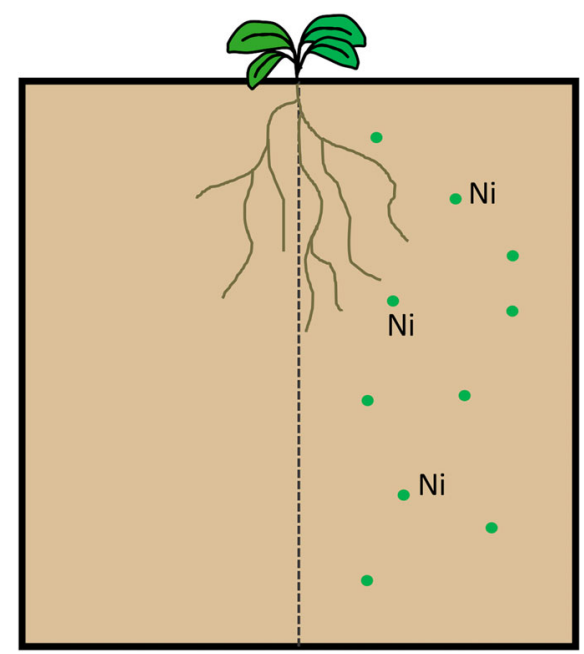

Fig. 1 Schematic view of a rhizotron filled in with a control soil on the left side and with $\mathrm{Ni}$ enriched soil on the right side as soon as cotyledons had appeared. Rhizotrons were then closed with the Petri dish cover plates, wrapped on the outside with aluminium foil to protect the roots from light and set up at an inclination of $45^{\circ}$ with the rooted surface facing down. The two Ni forms (carbonate and garnierite mineral) were tested for each plant accession of $N$. caerulescens and $S$. media and for each treatment three replicates were included for a total of 24 rhizotrons.

The experiment was conducted for 3 weeks in a growth cabinet with a $12-\mathrm{h} /$ day of light, a temperature of $20-25{ }^{\circ} \mathrm{C}$ (day-night), $75 \%$ humidity and light intensity of $350 \mu \mathrm{mol} \mathrm{m} \mathrm{sec}^{-1}$ photosynthetically active radiation (PAR).

Plant biomass analyses

Plant shoots were harvested after 3 weeks, carefully rinsed with deionized water and dried at $65{ }^{\circ} \mathrm{C}$ for $24 \mathrm{~h}$. The shoots were then weighed, grinded and digested in a mixture of $\mathrm{HNO}_{3}$ and $\mathrm{H}_{2} \mathrm{O}_{2}$ (with a ratio 5:1) in a digestion block at $115{ }^{\circ} \mathrm{C}$ for $158 \mathrm{~min}$ (Zhao et al. 1994). Pseudo-total element concentrations in the plant digests were measured with ICP-MS (Elan 9000 DRCe, Perkin Elmer) and with ICP-OES (Optima 8300, Perkin Elmer).

\section{Root density analyses}

\section{Pixel count method}

At the end of the growing period ( 3 weeks) and before the harvesting of shoots, high resolution images of all rhizotrons were taken with a Canon 5D MkII (24megapixel full-frame) camera with $50 \mathrm{~mm}$ prime lens. The images were then processed with the imaging software Image-J and converted to binary, where only black ("0") and white ("255") pixels were displayed (Fig. 2). The colours of the pictures were then inverted in order to obtain black roots on a white background. In the binary images, " 0 " (black/roots) and " 255 " (white/bulk soil) pixels were counted in each half of the rhizotrons with the Image-J program function "pixel count". Root density in the two areas of the rhizotrons was than measured as the percentage $(\%)$ of black pixels (roots) in each half calculated from the total black pixels on the full surface. 


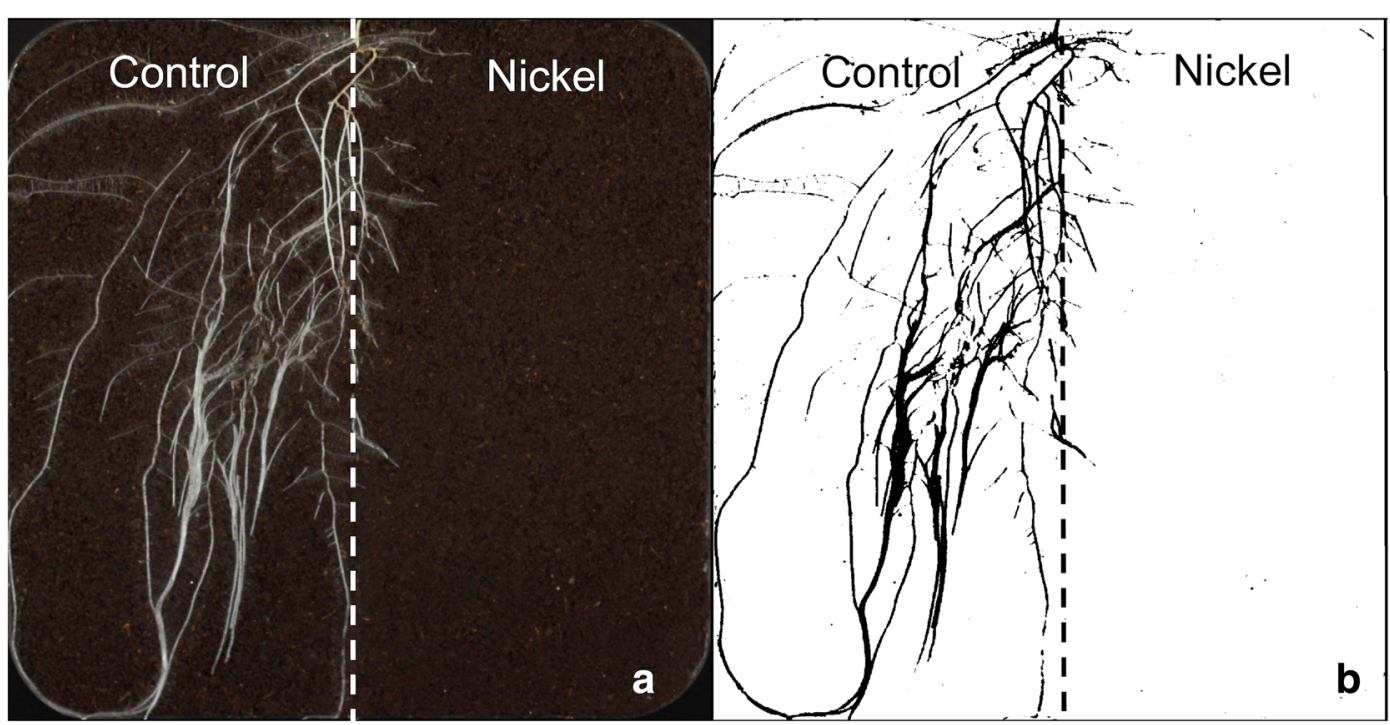

Fig. 2 Rhizotron rooted surface at the end of the experiment: a original picture and b converted to "bits" ("o" and "255" pixels) with the program Image-J in order to count black and white pixels

\section{Measurement of root biomass}

In addition to the pixel counts, roots were harvested from each half of the rhizotrons seperately, thoroughly rinsed to remove soil particles and oven dried at $65^{\circ} \mathrm{C}$ for $24 \mathrm{~h}$. Dry weight was recorded and the root density in each side was measured as a percentage of the total root density for each rhizotron. The results were then compared with the imaging method based on pixel counts.

\section{Statistical analyses}

Differences in shoot biomass as well as in root density in the Ni-spiked zones among all $N$. caerulescens and $S$. media treatments were assessed through one-way ANOVA and Tukey's HSD post-hoc tests. Welch ANOVA and the Games-Howell post-hoc tests were considered when homogeneity of variance was not met. Differences in root density \% between control and Ni-spiked soil zones within each treatment were assessed through Student's T test for independent samples. Correlations among Ni concentrations in the shoots and root density (pixel counts) in the $\mathrm{Ni}$ enriched soil were assessed through the Pearson's coefficient $r$. All statistical tests were performed with the program IBM SPSS statistics 24 considering a significance level of $p<0.05$.

\section{Results}

Soil characterization

The main characteristics of the control soil, such as $\mathrm{pH}$, pseudo-total and Ni DTPA-extractable concentrations $\left(\mathrm{Zn}_{\text {DTPA }}, \mathrm{Ni}_{\text {DTPA }}\right)$, Olsen-P, TOC, TN and texture, are shown in Table 1 . The control soil was characterized by neutral $\mathrm{pH}$ (6.98), high available $\mathrm{P}$ (49.3 $\mathrm{mg} \mathrm{kg}^{-1}$ ), high total organic content $(8.71 \mathrm{wt} \%)$ and total nitrogen $(0.50 \mathrm{wt} \%)$, sandy loam texture and low pseudo-total (9.36 $\left.\mathrm{mg} \mathrm{kg}^{-1}\right)$ and DTPA extractable (0.454 mg kg$\left.{ }^{-1}\right)$ $\mathrm{Ni}$ concentration. Enrichments with the garnierite mineral and $\mathrm{Ni}$-carbonate resulted, as expected, in a total $\mathrm{Ni}$ concentration of about $2000 \mathrm{mg} \mathrm{kg}^{-1}$ (Table 1). While the addition of garnierite resulted in a negligible $\mathrm{pH}$ variation (0.03 units), the $\mathrm{Ni}$-carbonate enrichment caused a $\mathrm{pH}$ rise of 0.45 units. Plant available Ni fraction resulted to be low $\left(3.63 \mathrm{mg} \mathrm{kg}{ }^{-1} \mathrm{Ni}_{\text {DTPA }}\right)$ in the garnierite-spiked soil, while a high $\mathrm{Ni}$ availability was measured in the Ni-carbonate treatment $\left(984 \mathrm{mg} \mathrm{kg}^{-1}\right.$ $\left.\mathrm{Ni}_{\text {DTPA }}\right)$.

\section{Shoot biomass}

Values of shoot dry weight are shown in Fig. 3. The Plombieres (Zn) accession of $N$. caerulescens resulted in a higher average biomass per plant $(131 \mathrm{mg}$ in the $\mathrm{Ni}$ carbonate treatment; $129 \mathrm{mg}$ in the garnierite treatment) 


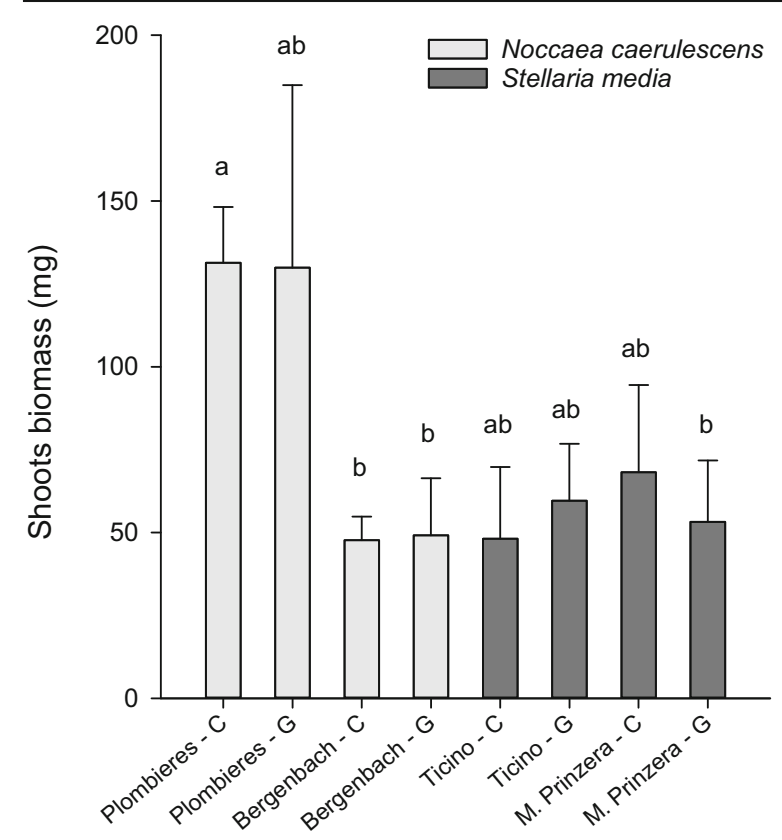

Fig. 3 Shoot dry weight (mg) of Noccaea caerulescens and Stellaria media. $\mathrm{C}=\mathrm{Ni}$ carbonate; $\mathrm{G}=$ Garnierite. Average values \pm standard deviation $(n=3)$. Different letters indicate statistical difference *Welch ANOVA and Games-Howell post hoc test, $p<0.05$ ) compared to the Bergenbach (Ni) accession $(47.7 \mathrm{mg}$ in the Ni-carbonate treatment; $49.1 \mathrm{mg}$ in the garnierite treatment), even if higher biomass values in the Plombieres accessions was statistical significant $(p<$ 0.05 ) only for the Ni-carbonate replicates. The two accessions of $S$. media had comparable biomass (Fig. 3). For both plant species, no significant differences in growth rates were recorded among the two different $\mathrm{Ni}$ treatments (Ni-carbonate and garnierite).

\section{Rooting density}

For all replicates of $N$. caerulescens and $S$. media, root growth over the transparent surface of the rhizotrons was successfully achieved, allowing for accurate observations and analyses of the root systems. Results of root density performed with the pixel count method and with measurement of root biomass $(\mathrm{mg})$ show a very high positive correlation coefficient (Pearson's correlation coefficient $r=0.93$ ); From the root density analyses (Figs. 4a and 5a) it can be observed that the Bergenbach (Ni) accession of $N$. caerulescens has a higher percentage of roots in the Ni-spiked soil, compared to the

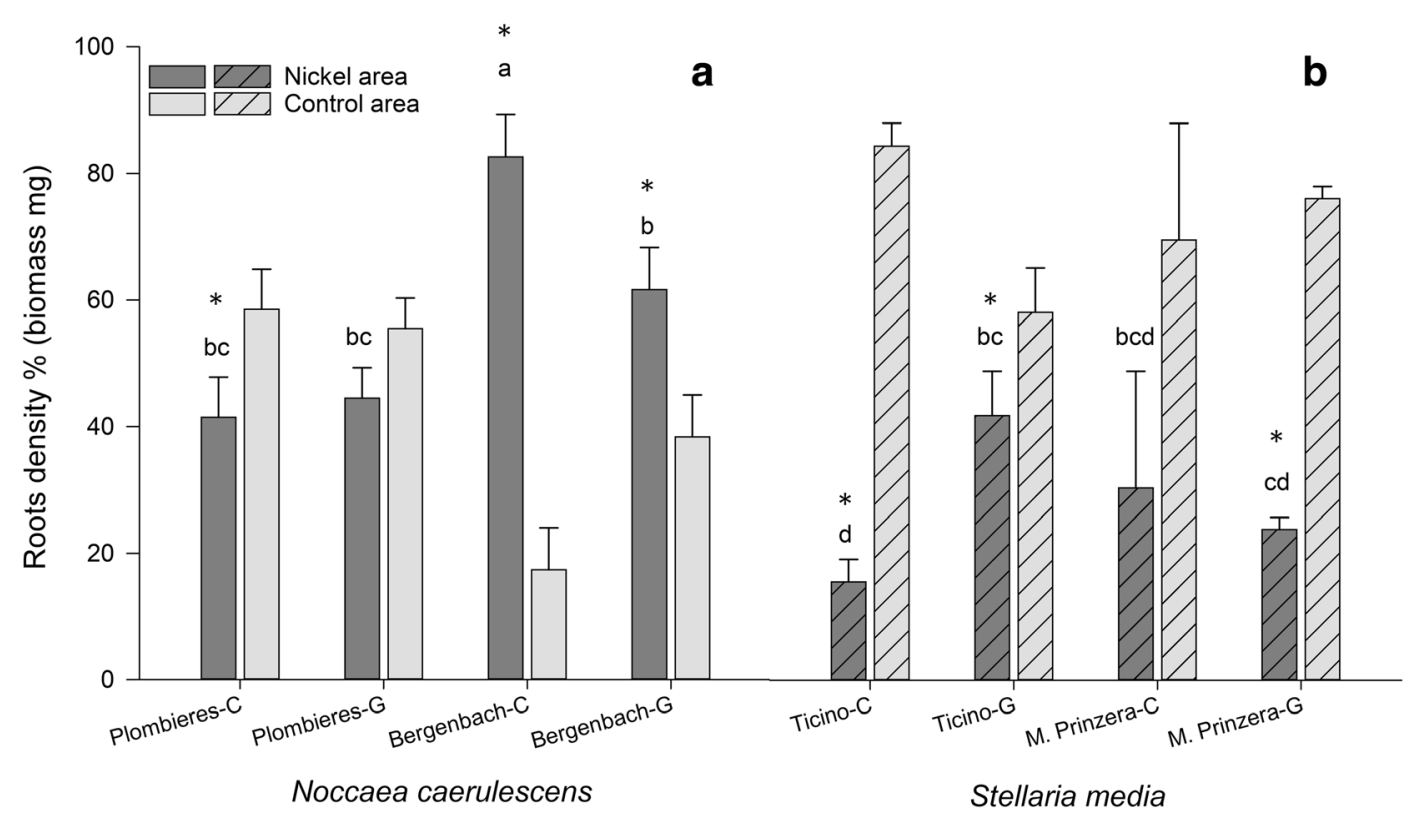

Fig. 4 Root density \% in the two areas of the rhizoton (nickel enriched and control) calculated from roots biomass (mg) for a Noccaea caerulescens and b Stellaria media. C=Ni carbonate; $\mathrm{G}=$ Garnierite. Average values \pm standard deviation $(n=3)$. Different letters indicate statistical difference (ANOVA and Turkey's
HSD post hoc test. $p<0.05$ ) in root density in the nickel enriched area among the different replicates. *indicates statistical difference (Student's T test. $p<0.05$ ) between the Ni-enriched and control area within the same replicates 


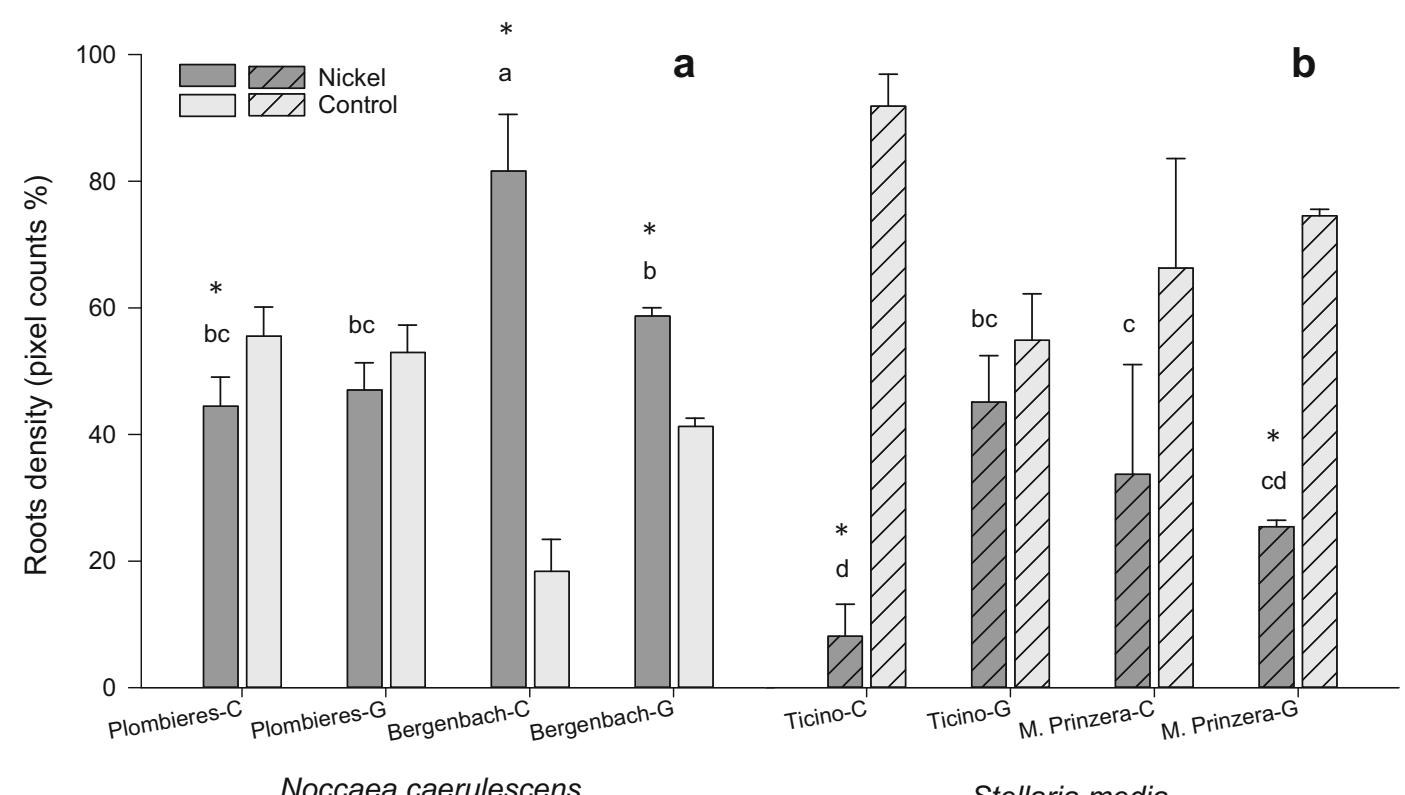

Noccaea caerulescens

Fig. 5 Root density \% in the two areas of the rhizoton (nickel enriched and control) calculated from imaging pixel counts for Noccaea caerulescens and Stellaria media. $\mathrm{C}=\mathrm{Ni}$ carbonate; $\mathrm{G}=$ Garnierite. Average values \pm standard deviation $(n=3)$. Different letters indicate statistical difference (ANOVA and Turkey's HSD

control soil; this trend was more pronounced in presence of $\mathrm{Ni}$-carbonate (roots/ $\mathrm{Ni}$ side: $81.6 \%$ pixel counts; $82.6 \%$ root biomass) than in the garnierite treatments (roots/Ni side: $58.7 \%$ pixel counts; $61.6 \%$ root biomass). Conversely, the Plombieres accession ( $\mathrm{Zn}$ ) had a slightly higher percentage of roots in the control side of the rhizotrons, with lower root density in the $\mathrm{Ni}$ carbonate spiked soil (roots/Ni side: $44.5 \%$ pixel counts; $41.5 \%$ root biomass), compared to the garnierite (roots/ Ni side: $47.0 \%$ pixel counts; $44.5 \%$ root biomass). Root growth in the Ni-spiked soil was higher in the Bergenbach (Ni) accession compared to the Plombieres $(\mathrm{Zn})$ accession for both $\mathrm{Ni}$ forms, even if it was statistically significant only for the $\mathrm{Ni}$ carbonate treatment.

In Stellaria media (Figs. 4b and 5b), the Ticino accession (non-metalliferous) had a significantly higher percentage of root growth in the control soil for the $\mathrm{Ni}$ carbonate treatment (roots/control: $91.8 \%$ pixel counts; $84.4 \%$ root biomass); even if not statistically significant for the "pixel count" values (Fig. 5b), a slightly higher root density in the control soil was observed for the garnierite treatment (root/control: $54.8 \%$ pixel counts; post hoc test. $p<0.05$ ) in root density in the nickel enriched area among the different replicates. *indicates statistical difference (Student's T test. $p<0.05$ ) between the Ni-enriched and control area within the same replicates

$58.1 \%$ root biomass) compared to the Ni enriched side. The ultramafic accession of $S$. media (Monte Prinzera) also resulted in a higher root density in the control side of the rhizotrons, with higher values (roots/control: $74.5 \%$ pixel counts; $76.1 \%$ root biomass) in the garnierite treatment than in the $\mathrm{Ni}$-carbonate treatment (roots/ control: $66.3 \%$ pixel counts; $69.6 \%$ root biomass); the difference between root density among control and $\mathrm{Ni}$ spiked soil in the Ni-carbonate treatment was not found to be statistically significant. It can also be observed that the $S$. media Ticino accession had a significantly lower $\%$ of roots in the Ni-carbonate spiked soil compared to the Monte Prinzera accession, while an opposite trend is seen in the garnierite treatment (Figs. $4 b$ and $5 b$ ).

Shoot concentrations of $\mathrm{Ni}$ and other elements

The Ni concentrations in shoots of $N$. caerulescens and $S$. media are shown in Table 2. For both accessions of $N$. caerulescens, a higher Ni uptake in the shoot was recorded in the presence of $\mathrm{Ni}$-carbonate (273 $\mathrm{mg} \mathrm{kg}^{-1}$ Plombieres accession; $5210 \mathrm{mg} \mathrm{kg}^{-1}$ Bergenbach accession) compared to the garnierite- 
Table 2 Total concentrations of Ni and other elements in the shoots of Noccaea caerulescens and Stellaria media.

\begin{tabular}{|c|c|c|c|c|c|c|c|c|}
\hline \multirow{3}{*}{$\begin{array}{l}\text { Plant species } \\
\text { Accession } \\
\mathrm{Ni} \text { form }\end{array}$} & \multicolumn{4}{|c|}{ Noccaea caerulescens } & \multicolumn{4}{|l|}{ Stellaria media } \\
\hline & \multicolumn{2}{|l|}{ Plombieres } & \multicolumn{2}{|l|}{ Bergenbach } & \multicolumn{2}{|l|}{ M. Prinzera } & \multicolumn{2}{|l|}{ Ticino } \\
\hline & Ni-Carbonate & Garnierite & Ni-Carbonate & Garnierite & Ni-Carbonate & Garnierite & Ni-Carbonate & Garnierite \\
\hline Ca $\frac{m g g^{-1}}{2}$ & $8390 \pm 27 \underline{a}$ & $7720 \pm 12 \underline{a}$ & $12,200 \pm 20 \underline{a}$ & $19,000 \pm 28 \underline{a}$ & $6220 \pm 8.5 \boldsymbol{e}$ & $4430 \pm 4.7 \underline{f}$ & $4800 \pm 13 \underline{\text { ef }}$ & $4060 \pm 24 f$ \\
\hline$\overline{\mathrm{Mg}} \overline{m g \mathrm{~kg}^{-1}}$ & $2480 \pm 42 \underline{\underline{a}}$ & $3000 \pm 33 \underline{\underline{a}}$ & $2860 \pm 21 \underline{\boldsymbol{a}}$ & $4200 \pm 8.5 \underline{\boldsymbol{a}}$ & $2520 \pm 23 \underline{e}$ & $1960 \pm 1.2 \underline{\boldsymbol{e}}$ & $2740 \pm 10 \underline{\underline{e}}$ & $2390 \pm 9.8 \underline{\boldsymbol{e}}$ \\
\hline $\mathrm{K} m g g^{-1}$ & $55,000 \pm 1 \overline{18} \underline{\boldsymbol{b}}$ & $47,200 \pm \overline{10} \underline{b}$ & $74,600 \pm \overline{30} \underline{a} \underline{b}$ & $103,700 \pm \overline{12} \underline{a}$ & $81,600 \pm 3 \overline{1}$ ef & $47,400 \pm 4 . \overline{7} \boldsymbol{f}$ & $99,600 \pm \overline{19} \underline{\boldsymbol{e}}$ & $88,200 \pm 1 \overline{e f}$ \\
\hline $\mathrm{P} \overline{m g g^{-1}}$ & $6850 \pm 35 \underline{c b}$ & $5750 \pm 11 \underline{c}$ & $19,400 \pm 43 \overline{a b}$ & $32,600 \pm 16 \underline{a}$ & $5920 \pm 2.8 \boldsymbol{e}$ & $6150 \pm 19 \underline{\text { ef }}$ & $8910 \pm 18 \boldsymbol{f}$ & $7820 \pm 15$ ef \\
\hline $\mathrm{Nimgkg^{-1 }}$ & $273 \pm 38 \boldsymbol{b}$ & $0.771 \pm 3 \bar{s}$ & $5210 \pm 33 a$ & $69.0 \pm 51 c$ & $21.5 \pm 47 \boldsymbol{e}$ & $<$ LOQ & $8.51 \pm 5.1 \boldsymbol{e}$ & $<$ LOQ \\
\hline $\mathrm{Zn} m g \mathrm{~kg}^{-1}$ & $1260 \pm 56 \underline{\boldsymbol{b}}$ & $1520 \pm 30 \underline{b}$ & $1410 \pm 77 \underline{b}$ & $4260 \pm 22 \underline{a}$ & $62.9 \pm 69 \underline{e}$ & $48.2 \pm 25 \underline{e}$ & $78.3 \pm 24 \underline{e}$ & $76.5 \pm 75 \underline{e}$ \\
\hline $\mathrm{Fe} m g \mathrm{~kg}^{-1}$ & $68.9 \pm 27 \underline{b}$ & $70.3 \pm 13 \underline{b}$ & $137 \pm 56 \underline{a b}$ & $203 \pm 6.2 \underline{a}$ & $73.1 \pm 59 \underline{e}$ & $61.3 \pm 17 \underline{e}$ & $92.5 \pm 18 \underline{e}$ & $77.5 \pm 41 \underline{e}$ \\
\hline$\overline{\mathrm{Mn}} \overline{m g k g^{-1}}$ & $193 \pm 54 \bar{a} \bar{b}$ & $68 \pm 28 \underline{\boldsymbol{b}}$ & $435 \pm 36 \overline{\boldsymbol{a}}$ & $215 \pm 20 \underline{\boldsymbol{a}}$ & $181 \pm 38 \underline{\boldsymbol{e}}$ & $54.6 \pm 8.4 \underline{f}$ & $130 \pm 15 \underline{\boldsymbol{e} f}$ & $89.8 \pm 39 \overline{\boldsymbol{f}}$ \\
\hline
\end{tabular}

Data show average values \pm relative standard deviation $\%(n=3)$. Statistical difference $(p<0.05)$ in element concentrations among accessions and treatments is indicated with different letters. LOQ (limit of quantification) was $0.251 \mu \mathrm{g} \mathrm{kg}^{-1}$

spiked soil $\left(0.771 \mathrm{mg} \mathrm{kg}^{-1}\right.$ Plombieres accession; $69.0 \mathrm{mg} \mathrm{kg}^{-1}$ Bergenbach accession), with higher concentrations recorded in the Bergenbach accession compared to the Plombieres accession. For $S$. media a similar trend can be observed (Table 2), as the $\mathrm{Ni}$ shoot concentrations are considerably higher in presence of $\mathrm{Ni}$-carbonate. As for $N$. caerulescens, the $\mathrm{Ni}$ accession (Monte Prinzera) of $S$. media also resulted in a greater $\mathrm{Ni}$ accumulation compared to the non-Ni accession (Ticino), even if no statistical significance was observed. Considering the $\mathrm{Ni}$ concentrations in the shoots of $N$. caerulescens and the \% of roots growing in the Ni spiked areas (pixel counts), a very strong positive correlation was recorded for the $\mathrm{Ni}$ carbonate (Pearson's $r$ 0.91; $p$ 0.01) and for the garnierite (Pearson's $r$ 0.91; $p$ 0.01) treatments. For $S$. media a very strong positive correlation coefficient (Pearson's $r$ 0.98; $p$ 0.002) is also found between the $\mathrm{Ni}$ concentrations in the shoots and the percentage of roots growing in the $\mathrm{Ni}$ carbonate spiked soil. It was not possible to assess correlations (Pearson's $r$ ) for the garnierite treatment, since the Ni shoot concentrations were below the limit of quantification (see Table 2).

Considering the $\mathrm{Zn}$ shoot concentrations (Table 2), the ultramafic $N$. caerulescens accession (Bergenbach) in the garnierite treatment had a significantly higher $\mathrm{Zn}$ accumulation (4260 mg kg-1) compared with the carbonate treatment and with the Plombieres accession for both treatments. No significant difference in $\mathrm{Zn}$ shoot concentrations in the $S$. media accession (M. Prinzera) was observed compared with the non-metalliferous accession (Ticino).

The $\mathrm{Ca}, \mathrm{K}$ and $\mathrm{P}$ shoot concentrations were higher in the ultramafic (Bergenbach) accession (Table 2), while $\mathrm{Mg}$ concentrations in $N$. caerulescens increased with higher Zn uptake (Pearson's $r$ 0.75; $p$ 0.005).

\section{Discussion}

Plant biomass

For both plant species, $N$. caerulescens and $S$. media, no significant differences in plant biomass were recorded within the same accession when growing in the presence of Ni-carbonate or garnierite (Fig. 3), indicating that variations in $\mathrm{Ni}$ supply did not influence plant growth. The higher Ni uptake in the shoot (Table 2) observed for the Ni-carbonate treatment in both plant species also did not affect plant biomass production. However, the $N$. caerulescens accession from the $\mathrm{Zn}$ contaminated site (Plombieres) had considerably higher biomass than the ultramafic accession (Bergenbach) (Fig. 3), even if it was not statistically significant for the Plombieres accession growing in the garnierite treatment. Variability in growth rates between the two accessions of 
$N$. caerulescens can be related to the natural morphological and physiological differences in accessions of this species (Ingrouille and Smirnoff 1986; Sterckeman et al. 2017). For example, nonmetalliferous accessions of $N$. caerulescens are often characterized by a lower biomass compared to accessions from metal-contaminated soils (Escarré et al. 2013). Comparing a large number of $N$. caerulescens accessions, it was observed that calamine accessions produce the greatest shoot biomass (Sterckeman et al. 2017), as also shown in our experiment. Haines (2002) reported that a higher plant biomass was obtained when roots of $N$. caerulescens were foraging for $\mathrm{Zn}$; in our results, this effect was not observed for $\mathrm{Ni}$, as no biomass variations were recorded in correspondence with higher Ni supply, Ni shoot uptake or root proliferation in Ni-enriched areas (Tables 1 and 2; Figs. 4 and 5). This suggests that, although the root proliferation in Ni-enriched soils is possibly driven by a higher physiological need of this element, high levels of $\mathrm{Ni}$ in the shoot are less essential than $\mathrm{Zn}$ in terms of plant growth for $N$. caerulescens. Nevertheless, it has to be considered that our experiment was conducted for a time period of 3 weeks, which limits interpretations and comparisons of our results in terms of biomass variations. For S. media, no significant differences in growth rates between the two accessions were observed. In this case, root avoidance of the $\mathrm{Ni}$-enriched soil areas might have contributed to reduce toxicity symptoms as, for instance, growth inhibition.

\section{Root foraging}

Considering the root density results of our experiment, the method based on pixel counts is a reliable approach for assessing root biomass in rhizotrons, as a very high correlation (Pearson's $r$ ) was observed between root biomass weight $(m g)$ and root density estimated through pixel counts. Therefore, root imaging analysis based on colour contrasts and pixel counts represent a valid and quick method for nondestructive assessments of root density in thin rhizotrons. Further tests should be conducted to define the applicability of this method to larger rhizotrons. The root density analysis (Figs. 4 and 5) has highlighted that the two $N$. caerulescens accessions $(\mathrm{Ni}$ accession and $\mathrm{Zn}$ accession) are exhibiting different root interactions with Ni enriched areas of the soil. With the more available Ni form (Ni-carbonate), the Plombieres accession (Zn) had a slight avoidance response to $\mathrm{Ni}$, while the Bergenbach (Ni) accession had an explicit preference for Ni enriched soils (Fig. 6). A less pronounced, but similar, response was observed in the presence of the less available Ni form (garnierite).

Our results clearly showed that the root systems of the $\mathrm{Ni}$ accession of $N$. caerulescens (Bergenbach) actively proliferate in $\mathrm{Ni}$-enriched soil zones. In a previous

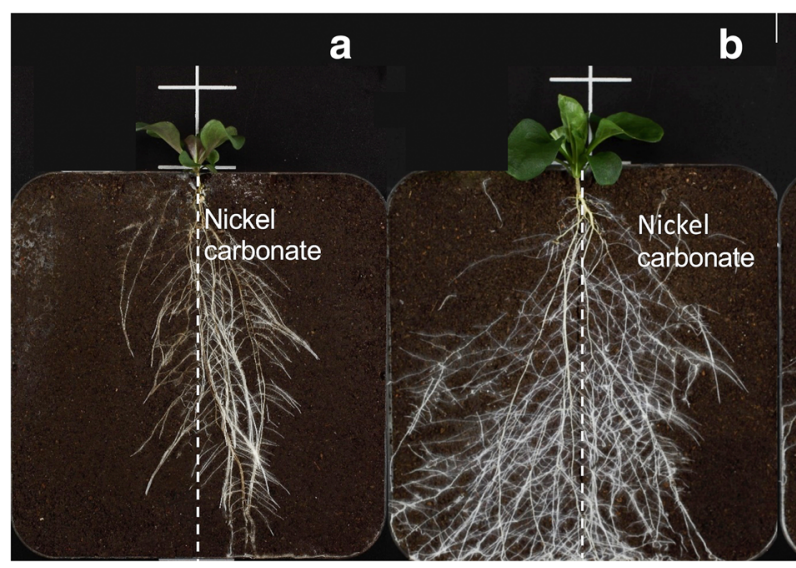

Fig. 6 Rhizotron rooted surfaces at the end of the experiment on the Ni-carbonate treatment with the Ni-spiked soil is on the right half of the rhizotrons: a $N$. caerulescens Bergenbach accession; $\mathbf{b}$

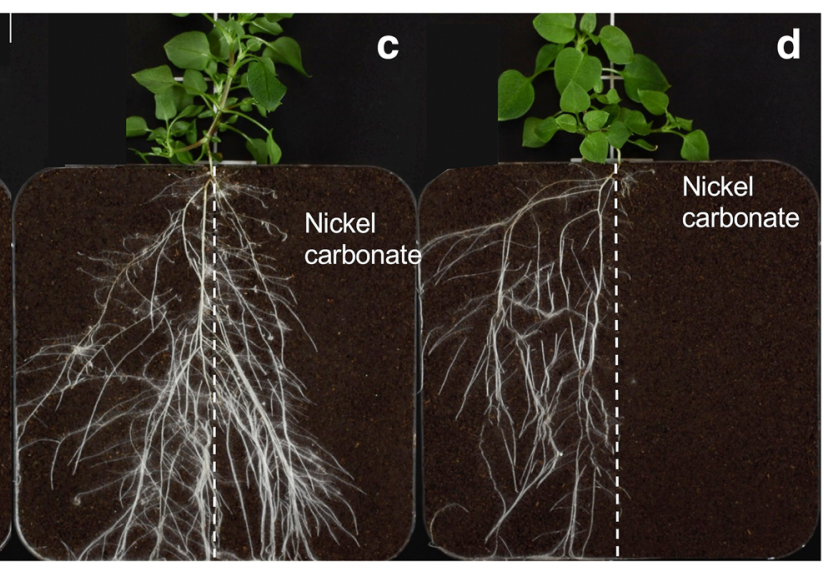

$N$. caerulescens Plombieres accession; c $S$. media Monte Prinzera accession and $\mathbf{d} S$. media Ticino accession 
Ni root foraging experiment, no effect on root allocation in $N$. caerulescens in relation to increasing localized total $\mathrm{Ni}$ concentrations in the substrate (at 250 and $500 \mathrm{mg} \mathrm{Ni} \mathrm{kg}{ }^{-1}$ ) were reported (Dechamps et al. 2008). Instead, our data showed that the Ni exploration responses in N. caerulescens (Bergenbach) was considerably more pronounced in presence of the highly available Ni form (carbonate), suggesting that a higher $\mathrm{Ni}$ supply is resulting in an increased root proliferation. The lower $\mathrm{Ni}$ concentrations and different $\mathrm{Ni}$ forms $(\mathrm{Ni}$ $(\mathrm{OH})_{2}$ ) tested in Dechamps et al. (2008) could explain these divergent results. Interestingly, $N$. caerulescens (Ni accession) was not only able to tolerate extremely high concentrations of plant-available $\mathrm{Ni}\left(\mathrm{Ni}_{\text {DTPA }}\right.$ $984 \mathrm{mg} \mathrm{kg}^{-1}$ ) but even to grow most of its roots in this area of the substrate. The less intense root proliferation in the Ni-enriched soil in the garnierite treatment is seemingly due to the lower $\mathrm{Ni}$ availability $\left(\mathrm{Ni}_{\text {DTPA }}\right.$ $3.63 \mathrm{mg} \mathrm{kg}^{-1}$ ), which resulted in a weaker response by the root systems. On the contrary, a slight $\mathrm{Ni}$ avoidance was recorded in the Plombieres ( $\mathrm{Zn})$ accession in the presence of garnierite. Contrasting root response (proliferation vs avoidance) towards $\mathrm{Ni}$ of the two $N$. caerulescens accessions suggest that adaptations to different substrate conditions result from different physiological requirements for this metal. While the Plombieres accession appears to tolerate Ni, but to moderately prefer a Ni-free soil, the Bergenbach accession is responding to $\mathrm{Ni}$ as if it was an essential nutrient. Increased root growth rate to patches where nutrients are most concentrated is recognized as a common response to nutrient availability (Hutchings and John 2003; Robinson 1994).

In their experiment conducted on $N$. caerulescens, Whiting et al. (2000) observed a root proliferation response to $\mathrm{Zn}$ enriched soil patches and suggested that zincophilic accessions of $N$. caerulescens might be actively foraging for $\mathrm{Zn}$ in the soil. Haines (2002) also reported a $\mathrm{Zn}$ foraging response in $N$. caerulescens, even resulting in higher $\mathrm{Zn}$ shoot concentrations for one of the tested accessions (Prayon). Positive root proliferation in $\mathrm{Cd}$-enriched soil patches has also been reported for $N$. caerulescens (Whiting et al. 2000; Schwartz et al. 2003).

The results of Dechamps et al. (2008) showed equal rooting allocation (root biomass) between right and left compartments of the rhizotrons by $N$. caerulescens when growing on uncontaminated or homogeneously metal-spiked substrates, while a higher root allocation of up to $60 \%$ by a calamine accession (Prayon) in the $\mathrm{Ni}$ enriched compartment (placed either on the right or left side of the rhizotrons) was observed when localized $\mathrm{Ni}$ enrichments were tested. Conversely, our results show that the calamine $N$. caerulescens accession (Plombieres) slightly avoids $\mathrm{Ni}$ on the right (Ni-rich) rhizotron compartment. Different responses of the Prayon (Dechamps et al. 2008) and Plombieres accessions to Ni could be related to different experimental soil characteristics, for instance, $\mathrm{pH}$ values $(6.98$, see Table 1; 4.65 in Dechamps et al. 2008) or Zn availability, as well as to the $\mathrm{Ni}$ forms tested $\left(\mathrm{Ni}(\mathrm{OH})_{2}\right.$ in Dechamps et al. 2008). In addition, in Dechamps et al. (2008) no $\mathrm{pH}$ adjustment has been performed on the "control" rhizotron compartment, where an increase in $\mathrm{pH}$ could be expected due to the dissolution of $(\mathrm{Ni}$ $\left.(\mathrm{OH})_{2}\right)$. Possibly, less pronounced Ni foraging responses in Dechamps et al. (2008) compared with the Bergenbach (Ni) accession tested in our experiment can be related to the lower total $\mathrm{Ni}$ concentrations in Dechamps et al. (2008) (and presumably to lower Ni availability). Furthermore, the shorter growth period in our experiment (3 weeks) compared to Dechamps et al. (2008) (3 months) seemingly led to clearer observations in terms of foraging responses, as with longer growth times root colonization of the substrate plausibly proceeds in both rhizotrons compartments due to space limitations.

In $S$. media, clear root Ni avoidance was observed in both accessions (Figs. 4b, 5b and 6), with the effect being more evident in the presence of the more available metal form (Ni carbonate). Cadmium avoidance was observed in the non-accumulator Lupinus albus (Schwartz et al. 2003), and the same response was reported with the non-accumulators Thlaspi arvense in the presence of $\mathrm{Zn}$ (Whiting et al. 2000) and Cicer arietinum in the presence of Ni (Moradi et al. 2009). To date, no evidence of such root avoidance by metal tolerant plant species have been described for Ni. Being from a non-metalliferous soil, the higher root avoidance of $S$. media Ticino accession in the presence of $\mathrm{Ni}$-carbonate could be expected, while the higher exclusion response of $S$. media from Mt. Prinzera accession to the garnierite mineral cannot be easily explained. It is likely that this accession, adapted to ultramafic conditions, is more efficient at "detecting" $\mathrm{Ni}$ than the non-metalliferous accession, thus avoiding Ni-enriched patches more effectively. Our results suggest that metal excluder plant species growing in ultramafic environments might proliferate roots in 
lower-Ni soil patches and that root avoidance might play a role in their metal tolerance.

\section{Shoot concentrations of $\mathrm{Ni}$ and other elements}

The higher Ni availability in the Ni carbonate treatment resulted in higher Ni shoot concentrations in both $N$. caerulescens and $S$. media (Table 2). The remarkably higher Ni shoot uptake (Table 2) observed in the $\mathrm{Ni}$ accession (Bergenbach) of $N$. caerulescens compared to the non-Ni accession (Plombieres) is again highlighting divergent responses to Ni supply between the two accessions. Only the $\mathrm{Ni}$ accession of $N$. caerulescens (Bergenbach) growing in the $\mathrm{Ni}$ carbonate treatment resulted in a high $\mathrm{Ni}$ shoot concentration $(5210 \mathrm{mg} \mathrm{Ni}$ $\mathrm{kg}^{-1}$, Table 2) which is higher than the hyperaccumulation threshold of $1000 \mathrm{mg} \mathrm{Ni} \mathrm{kg} \mathrm{m}^{-1}$ (Baker et al. 2000; Brooks et al. 1977; Reeves et al. 1996; van der Ent et al. 2013). Literature values from field specimen of the Bergenbach accession (N. caerulescens) report shoot $\mathrm{Ni}$ concentrations ranging from 396 to $3057 \mathrm{mg} \mathrm{kg}^{-1}$ (Chardot et al. 2007), with soil $\mathrm{Ni}_{\text {DTPA }}$ concentrations up to about $100 \mathrm{mg} \mathrm{kg}$ ${ }^{-1}$. In our results, a high $\mathrm{Ni}$ availability $\left(\mathrm{Ni}_{\mathrm{DTPA}} ; \mathrm{Ni}-\right.$ carbonate treatment) in the substrate resulted in a greater Ni shoot uptake by this accession. As in our experiment, Chardot et al. (2007) also observed that Ni concentrations in the shoot of $N$. caerulescens were significantly correlated with available $\mathrm{Ni}$ in the substrate, showing that Ni uptake responds to Ni availability. Dechamps et al. (2008) also reported higher Ni shoot uptake in presence of higher Ni concentrations in the substrate. Other studies on field specimen from Bergenbach (Reeves et al. 2001) reported shoot concentrations of 4625 to $8783 \mathrm{mg} \mathrm{Ni} \mathrm{kg}{ }^{-1}$. Surprisingly, in our experiment lower concentrations were achieved, despite the extremely high $\mathrm{Ni}$ availability in the substrate (Ni-carbonate treatment); seemingly, the fact that a fraction of the root system was growing on the control soil might have limited the maximum shoot concentrations achieved.

High $\mathrm{Zn}$ uptake in the Ni carbonate treatment (Bergenbach accession: $1410 \mathrm{mg} \mathrm{Zn} \mathrm{kg}{ }^{-1}$ ) might also have inhibited Ni accumulation. Also, it has to be considered that a shorter growth period (3 weeks) in our experiment might have contributed to limited Ni uptake compared to field specimens of $N$. caerulescens. In contrast to the Bergenbach accession, $N$. caerulescens from Plombieres had a low $\mathrm{Ni}$ accumulation rate (0.771 mg kg ${ }^{-1}$; Table 2) typical of non-metalliferous plant species when growing in the garnierite treatment. In fact, the leaves of most plant species growing on nonmetalliferous soils normally contain $\mathrm{Ni}$ concentrations in shoot dry biomass $<10 \mathrm{mg} \mathrm{kg}^{-1}$ (Reeves et al. 1980). A higher Ni uptake by ultramafic accessions of $N$. caerulescens compared to calamine accessions, has also been validated by genetic studies of Ni tolerance, as described previously (Assunção et al. 2003a). Comparing $\mathrm{Cd}$ adaptation mechanisms in two $\mathrm{Zn} / \mathrm{Cd}$ accessions of $N$. caerulescens, Halimaa et al. (2019) hypothesises that $\mathrm{Cd}$ exclusion in the La Calamine accession might play a role in $\mathrm{Cd}$ tolerance. A similar exclusion mechanism might explain the lower $\mathrm{Ni}$ uptake in the Plombieres accession (which is close to La Calamine). Observing differential root growth in $\mathrm{Zn}$ enriches patches, Whiting et al. (2000) suggested that $N$. caerulescens might be capable of zincophilic root foraging responses, but were unable to correlate root proliferation with increased $\mathrm{Zn}$ uptake and thus to demonstrate that these were $\mathrm{Zn}$-foraging responses. In our results, the strong positive correlation (Pearson's $r, p<$ 0.05 ) observed in both accessions between $\mathrm{Ni}$ shoot concentrations and root density in the Ni-enriched zone confirms that $N$. caerulescens is actively foraging for $\mathrm{Ni}$ and suggests that a higher uptake of this metal follows a higher physiological requirement.

Reported values of Ni in shoots of $S$. media grown in hydroponic culture range from $166 \mathrm{mg} \mathrm{kg}^{-1}$ to $250 \mathrm{mg} \mathrm{kg}^{-1}$ (Salinitro et al. 2020). In our experiment, the maximum $\mathrm{Ni}$ shoot concentrations in S. media were observed, as for $N$. caerulescens, in the Ni-carbonate treatment for the Ni accession of M. Prinzera $(21.5 \mathrm{mg}$ $\mathrm{Ni} \mathrm{kg}^{-1}$ ), with lower values for the low $\mathrm{Ni}$ accession from Ticino ( $8.51 \mathrm{mg} \mathrm{Ni} \mathrm{kg}^{-1}$ ). The very strong positive correlation between $\mathrm{Ni}$ shoot concentrations and root density in the control soil observed for the Ni-carbonate treatment in $\mathrm{S}$. media suggests that rooting $\mathrm{Ni}$ avoidance could be a strategy aimed at limiting shoot Ni uptake. According to the definition of excluder plants (Baker 1981), the Ni concentrations in the shoos should remain constant over a range of soil concentrations. Conversely, we observed that higher exposure (through higher root density in the $\mathrm{Ni}$ enriched soil) results in a higher $\mathrm{Ni}$ concentration in the shoots (Table 2). The fact that with garnierite the shoot Ni concentrations in both $S$. media accessions are non-detectable shows that Ni exclusion effectively limited Ni uptake. Presumably, S. media is 
capable of avoiding Ni enriched soil patches, but when roots are exposed to elevated Ni supply, exclusion mechanisms are limited.

Despite the fact that the highest $\mathrm{Zn}$ shoot concentrations in $N$. caerulescens are most frequently observed in calamine accessions (Sterckeman et al. 2017), higher Zn shoot accumulation were reported in non-metalliferous and ultramafic accessions compared to calamine accessions (Escarré et al. 2000, 2013). Dechamps et al. (2008) also report higher $\mathrm{Zn}$ uptake in a nonmetalliferous accession compared to a calamine accession. Thus, the higher shoot $\mathrm{Zn}$ uptake in the ultramafic (Bergenbach) accession (Table 2) is not unexpected. The results of Escarré et al. (2013) suggest that ultramafic accessions of $N$. caerulescens might behave like a non-metalliferous accession, with enhanced capacities of shoot $\mathrm{Zn}$ uptake due to low availability in their habitats; this could indeed clarify the higher shoot $\mathrm{Zn}$ uptake observed in the ultramafic (Bergenbach) accession in our experiment. On the other hand, the lower $\mathrm{Zn}$ uptake in presence of $\mathrm{Ni}$-carbonate could be related to ion competition. Escarré et al. (2013) also observed that $\mathrm{Ni}$ addition to a $\mathrm{Zn}$ rich soil significantly decreased $\mathrm{Zn}$ concentrations in the shoot of $N$. caerulescens. In contrast, a strongly positive correlation between $\mathrm{Ni}$ and $\mathrm{Zn}$ concentrations in shoots of $N$. caerulescens have been reported (Sterckeman et al. 2017). These contrasting findings (co-transport vs antagonism) may relate to the relative $\mathrm{Ni}$ and $\mathrm{Zn}$ concentrations tested: while co-transport might occur at balanced and moderate concentrations, antagonism might take place when $\mathrm{Zn}$ or $\mathrm{Ni}$ are present at high concentrations, as shown in our results (in the Ni carbonate treatment). The lower $\mathrm{P}, \mathrm{K}$ and $\mathrm{Fe}$ shoot concentrations found in our study in the Plombieres accession (Table 2) contradict results of Sterckeman et al. (2017), who reported that calamine accessions contain higher concentrations of these elements in the shoots than ultramafic accessions; only the higher shoot $\mathrm{Ca}$ values in the ultramafic (Bergenbach) accessions are in accordance with Sterckeman et al. (2017). These contradicting results could be related to variations in substrates conditions as well as differences in the growing period. Furthermore, the significant positive correlation between $\mathrm{Zn}$ and $\mathrm{Mg}$ shoot concentrations confirms findings of Dechamps et al. (2005, 2008), who hypothesize the involvement of common transporters for these two elements in $N$. caerulescens.

\section{Conclusions}

This study represents the first investigation on root growth responses to artificially $\mathrm{Ni}$ enriched soil comparing ultramafic and calamine $N$. caerulescens accessions and differential accessions of a metal tolerant plant species (S. media). We have demonstrated that accessions adapted to different substrates conditions exhibit divergent root growth responses in the presence of $\mathrm{Ni}$. Accessions adapted to ultramafic soils appear to have an evident preference for $\mathrm{Ni}$ and positive root proliferation in Ni-enriched soils, that consequently enhanced $\mathrm{Ni}$ shoot uptake. Thus, we can conclude that a foraging response was observed in the ultramafic accession of $N$. caerulescens, while a slight $\mathrm{Ni}$ avoidance was observed in the non-ultramafic accession. In S. media, we have described for the first time the root responses of a metal tolerant (excluder) plant species in the presence of soil Ni. Our study suggests that foraging and avoidance of Ni represent different adaptation strategies in ultramafic soils to either support efficient Ni uptake in hyperaccumulators or to assist in metal exclusion in non-accumulating plant species. Further studies should be conducted to better clarify the physiological mechanisms behind these rooting responses to Ni-enriched soils.

Acknowledgments We would like to acknowledge the Sustainable Mineral Institute of The University of Queensland, where the experiment was conducted, for hosting Alice Tognacchini as visiting $\mathrm{PhD}$ student and the AMS Arbeitsmarktservice of Austria for supporting her stay abroad during the research. We would also like to thank Guillaume Echevarria for providing seeds of Noccaea caerulescens.

Funding Information Open access funding provided by University of Natural Resources and Life Sciences Vienna (BOKU).

Open Access This article is licensed under a Creative Commons Attribution 4.0 International License, which permits use, sharing, adaptation, distribution and reproduction in any medium or format, as long as you give appropriate credit to the original author(s) and the source, provide a link to the Creative Commons licence, and indicate if changes were made. The images or other third party material in this article are included in the article's Creative Commons licence, unless indicated otherwise in a credit line to the material. If material is not included in the article's Creative Commons licence and your intended use is not permitted by statutory regulation or exceeds the permitted use, you will need to obtain permission directly from the copyright holder. To view a copy of this licence, visit http://creativecommons.org/licenses/by/4.0/. 


\section{References}

Assunção AGL, Bookum WM, Nelissen HJM, Vooijs R, Schat H, Ernst WHO (2003a) Differential metal specific tolerance and accumulation patterns among Thlaspi caerulescens populations originating from different soil types. New Phytol 159: 411-419

Assunção AG, Schat H, Aarts MG (2003b) Thlaspi caerulescens, an attractive model species to study heavy metal hyperaccumulation in plants. New Phytol 159:351-360

Baker AJM (1981) Accumulators and excluders-strategies in the response of plants to heavy metals. J Plant Nutr 3:643-654

Baker AJM (1987) Metal tolerance. New Phytol 106:93-111

Baker AJM, Brooks R (1989) Terrestrial higher plants which hyperaccumulate metallic elements. A review of their distribution, ecology and phytochemistry. Biorecovery 1:81-126

Baker AJM, Reeves RD, McGrath SP (1991) In situ decontamination of heavy metal polluted soils using crops of metalaccumulating plants - a feasibility study. In: Hinchee RL, Olfenbuttel RF (eds) In situ bioreclamation. Butterworth, Boston, pp 600-605

Baker AJM, Reeves RD, Hajar ASM (1994) Heavy metal accumulation and tolerance in British populations of the metallophyte Thlaspi caerulescens J \& C. Pres1. (Brassicaceae). New Phytol 127:61-68

Baker AJM, McGrath SP, Reeves RD, Smith JAC (2000) Metal hyperaccumulator plants: a review of ecology and physiology of a biological resource for phytoremediation of metalpolluted soils. In: Terry $\mathrm{N}$ et al (eds) Phytoremediation of contaminated soil and water. Lewis Publishers, Boca Raton, pp 129-158

Brooks RR (1998) Phytochemistry of hyperaccumulation. In: Brooks RR (ed) Plants that Hyperaccumulate metals. CAB International, Wallingford, UK, pp 261-287

Brooks RR, Lee J, Reeves RD, Jaffre T (1977) Detection of nickeliferous rocks by analysis of herbarium specimens of indicator plants. J Geochem Explor 7:49-57

Brown SL, Chaney RL, Angle JS, Baker AJM (1994) Phytoremediation potential of Thlaspi caerulescens and bladder campion for zinc- and cadmium-contaminated soil. J Environ Qual 23:1151-1157

Brown SL, Chaney RL, Angle JS, Baker AJM (1995) Zinc and cadmium uptake by hyperaccumulator Thlaspi caerulescens grown in nutrient solution. J Soil Sci Soc Am 59:125-133

Callahan DL, Hare DJ, Bishop DP, Doble PA, Roessner U (2016) Elemental imaging of leaves from the metal hyperaccumulating plant Noccaea caerulescens shows different spatial distribution of $\mathrm{Ni}, \mathrm{Zn}$ and $\mathrm{Cd}$. RSC Adv 6: $2337-2344$

Casper BB, Jackson RB (1997) Plant competition underground. Annu Rev Ecol S 28:545-570

Chardot V, Echevarria G, Gury M, Massoura S, Morel JL (2007) Nickel bioavailability in an ultramafic toposequence in the Vosges Mountains (France). Plant Soil 293:7-21

Craciun AR, Meyer CL, Chen J, Roosens N, De Groodt R, Hilson $P$ et al (2012) Variation in HMA4 gene copy number and expression among Noccaea caerulescens populations presenting different levels of cd tolerance and accumulation. J Exp Bot 63:4179-4189
Dechamps C, Roosens NH, Hotte C, Meerts P (2005) Growth and mineral element composition in two ecotypes of Thlaspi caerulescens on Cd contaminated soil. Plant Soil 273:327335

Dechamps C, Noret N, Mozek R, Draye X, Meerts P (2008) Root allocation in metal-rich patch by Thlaspi caerulescens from normal and metalliferous soil-new insights into the rhizobox approach. Plant Soil 310(1-2):211-224

Dessureault-Rompré J, Luster J, Schulin R, Tercier-Weiber M-L, Nowack B (2010) Environ Pollut 158:1955-1962

Escarré J, Lefèbvre C, Gruber W, Leblanc M, Lepart J, Rivière Y, Delay B (2000) Zinc and cadmium accumulation by Thlaspi caerulescens from metalliferous and nonmetalliferous sites in the Mediterranean area: implications for phytoremediation. New Phytol 145:429-437

Escarré J, Lefèbvre C, Frérot H, Mahieu S, Noret N (2013) Metal concentration and metal mass of metallicolous, non metallicolous and serpentine Noccaea caerulescens populations, cultivated in different growth media. Plant Soil 370: 197-221

Fitter AH (1994) Architecture and biomass allocation as components of the plastic response of root systems to soil heterogeneity. In: Caldwell MM, Pearcy RW (eds) Exploitation of environmental heterogeneity by plants: ecophysiological processes above- and belowground. Academic Press, San Diego, pp 305-323

Gonneau G, Genevois N, Frérot H, Sirguey C, Sterckeman T (2014) Variation of trace metal accumulation, major nutrient uptake and growth parameters and their correlations in 22 populations of Noccaea caerulescens. Plant Soil 384:271287

Gonneau C, Noret N, Godé C, Frérot H, Sirguey C, Sterckeman T, Pauwels M (2017) Demographic history of the trace metal hyperaccumulator Noccaea caerulescens (J. Presl and C. Presl) F. K. Mey. In: Western Europe. Molec. Ecology 26: 904-922

Guan P, Wang R, Nacry P, Breton G, Kay SA, Pruneda-Paz JL, Davani A, Crawford NM (2014) Nitrate foraging by Arabidopsis roots is mediated by the transcription factor TCP20 through the systemic signaling pathway. PNAS 111(42):15267-15272

Haines BJ (2002) Zincophilic root foraging in Thlaspi caerulescens. New Phytol 155:363-372

Halimaa P, Lin YF, Ahonen VH, Blande D, Clemens S, Gyenesei A et al (2014) Gene expression differences between Noccaea caerulescens ecotypes help to identify candidate genes for metal phytoremediation. Environ Sci Technol 48:3344-3353

Halimaa P, Blande D, Baltzi E, Aarts MGM, Granlund L, Keinänen M, Kärenlampi SO, Kozhevnikova AD, Peräniemi S, Schat H, Seregin IV, Tuomainen M, Tervahauta AI (2019) Transcriptional effects of cadmium on iron homeostasis differ in calamine accessions of Noccaea caerulescens. Plant J 97:306-320

Hammer D, Keller C (2003) Phytoextraction of Cd and Zn with Thlaspi caerulescens in field trials. Soil Use Manag 19:144 149

Hanikenne M, Nouet C (2011) Metal hyperaccumulation and hypertolerance: a model for plant evolutionary genomics. Curr Opin Plant Biol 14:252-259

Hodge A (2004) The plastic plant: root responses to heterogeneous supplies of nutrients. New Phytol 162:9-24 
Hutchings MJ, de Kroon H (1994) Foraging in plants: the role of morphological plasticity in resource acquisition. Adv Ecol Res 25:159-238

Hutchinson JJ, Young SD, McGrath SP, West HM, Black CR, Baker AJM (2000) Determining uptake of 'non-labile' soil cadmium by Thlaspi caerulescens using isotopic dilution techniques. New Phytol 146:453-460

Hutchings MJ and John EA (2003) Distribution of roots in soil, and root foraging activity. In: de Kroon H, Visser EJW (eds) Root ecology. Ecological Studies (Analysis and Synthesis), vol 168. Springer, Berlin, Heidelberg

Ingrouille MJ, Smirnoff N (1986) Thlaspi caerulescens J. \& C. Presl. (T. alpestre L.) in Britain. New Phytol 102:219-233

Jacobs A, Drouet T, Sterckeman T, Noret N (2017) Phytoremediation of urban soils contaminated with trace metals using Noccaea caerulescens: comparing nonmetallicolous populations to the metallicolous 'Ganges' in field trials. Environ Sci Pollut Res 24:8176-8188

Jacobs A, Drouet T, Noret N (2018) Field evaluation of cultural cycles for improved cadmium and zinc phytoextraction with Noccaea caerulescens. Plant Soil 430:381-394

Krämer U (2005) Phytoremediation: novel approaches to cleaning up polluted soils. Curr Opin Biotechnol 16:133-141

Krämer U (2010) Metal hyperaccumulation in plants. Annu Rev Plant Biol 61:517-534

Krämer U, Cotter-Howells JD, Charnock JM, Baker AJM, Smith JAC (1996) Free histidin as a metal chelator in plants that hyperaccumulate nickel. Nature 379:635-638

Krämer U, Smith RD, Wenzel WW, Raskin I, Salt DE (1997) The role of metal transport and tolerance in nickel hyperaccumulation by Thlaspi goesingense Hálácsy. Plant Physiol 115:1641-1650

Krämer U, Pickering IJ, Prince RC, Raskin I, Salt DE (2000) Subcellular localization and speciation of nickel in hyperaccumulator and non-accumulator Thlaspi species. Plant Physiol 122:1343-1353

Lasat MM, Baker AJM, Kochian LV (1996) Physiological characterization of root $\mathrm{Zn}^{2+}$ absorption and translocation to shoots in $\mathrm{Zn}$ hyperaccumulator and nonaccumulator species of Thlaspi. Plant Physiol 112:1715-1722

Lindsay WL, Norvell WA (1978) Development of a DTPA soil test for zinc, iron, manganese and copper. Soil Sci Soc Am J 41: 421-428

Liu F, Tang Y, Du R, Yang H, Wu Q, Qiu R (2010) Root foraging for zinc and cadmium requirement in the $\mathrm{Zn} / \mathrm{Cd}$ hyperaccumulator plant Sedum alfredii. Plant Soil 327:365375

Lombi E, Wenzel WW, Gobran GR, Adriano DC (2000) Dependency of phytoavailability of metals on indigenous and induced rhizosphere processes: a review. In: Gobran GR, Wenzel WW, Lombi E (eds) Trace elements in the Rhizosphere. CRC Press LLC, Boca Raton, pp 3-24

Lombini A, Dinelli E, Ferrari C, Simoni A (1998) Plant-soil relationships in the serpentinite sources of Mt. Prinzera (northern Apennines, Italy). J Geochem Explor 64:19-33

McGrath SP, Sidoli CMD, Baker AJM, Reeves RD (1993) The potential for the use of metal-accumulating plants for the in situ decontamination of metal-polluted soils. In: Eijsackers $\mathrm{H}$, Hamers $\mathrm{T}$ (eds) Integrated soil and sediment research: a basis for proper protection. Kluwer Academic Press, Dordrecht, pp 673-676
McGrath SP, Shen ZG, Zhao FJ (1997) Heavy metal uptake and chemical changes in the rhizosphere of Thlaspi caerulescens and Thlaspi ochroleucum grown in contaminated soils. Plant Soil 188:153-159

McGrath SP, Lombi E, Gray CW, Caille N, Dunham SJ, Zhao FJ (2006) Field evaluation of $\mathrm{Cd}$ and $\mathrm{Zn}$ phytoextraction potential by the hyperaccumulators Thlaspi caerulescens and Arabidopsis halleri. Environ Pollut 141:115-125

Meerts P, Isacker NV (1997) Heavy metal tolerance and accumulation in metallicolous and non-metallicolous populations of Thlaspi caerulescens from continental Europe. Plant Ecol 133:221-231

Merlot S, Sanchez Garcia De la Torre V, Hanikenne M (2018) Physiology and molecular biology of trace elements hyperaccumulation. In: van der Ent A, Echevarria G, Baker AJM, Morel JL (eds) Agromining: farming for metals extracting unconventional resources using plants. Springer International Publishing, Cham, pp 93-116

Meyer FK (2006) Kritische Revision der "Thlaspi"-Arten Europas, Afrikas und Vorderasiens. Spezieller Teil. IX. Noccaea MOENCH. Thüringische Botanische Gesellschaft, Haussknechtia Suppl 12.343p

Meyer CL, Juraniec M, Huguet S, Chaves-Rodriguez E, Salis P, Isaure MP, Goormaghtigh E, Verbruggen N (2015) Intraspecific variability of cadmium tolerance and accumulation, and cadmium-induced cell wall modifications in the metal hyperaccumulator Arabidopsis halleri. J Exp Bot 66: 3215-3227

Milner MJ, Kochian LV (2008) Investigating heavy-metal hyperaccumulation using Thlaspi caerulescens as a model system. Ann Bot 102:3-13

Milner MJ, Craft E, Yamaji N, Koyama E, Ma JF, Kochian LV (2012) Characterization of the high affinity $\mathrm{Zn}$ transporter from Noccaea caerulescens, NcZNT1, and dissection of its promoter for its role in $\mathrm{Zn}$ uptake and hyperaccumulation. New Phytol 195:113-123

Moradi AB, Conesa HM, Robinson BH, Lehmann E, Kaestner A, Schulin R (2009) Root responses to soil Ni heterogeneity in a hyperaccumulator and a non-accumulator species. Environ Pollut 157:2189-2196

Murphy J, Riley J (1962) A modified single solution method for the determination of phosphate in natural waters. Anal Chim Acta 27:31-36

Olsen S, Cole C, Watanabe F, Dean L (1954) Estimation of available phosphorus in soils by extraction with sodium bicarbonate

Ozturk L, Karanlik S, Ozkutlu F, Cakmak I, Kochian LV (2003) Shoot biomass and zinc/cadmium uptake for hyperaccumulator and non-accumulator Thlaspi species in response to growth on a zinc-deficient calcareous soil. Plant Sci 164:1095-1101

Peer WA, Mamoudian M, Lahner B, Reeves RD, Murphy AS, Salt DE (2003) Identifying model metal hyperaccumulating plants: germplasm analysis of 20 Brassicaceae accessions from a wide geographical area. New Phytol 159:421-430

Puschenreiter M, Wieczorek S, Horak O, Wenzel W (2003) Chemical changes in the rhizosphere of metal hyperaccumulator and excluder Thlaspi species. J Plant Nutr Soil Sci 166:579-584

Reeves RD, Baker AJM (2000) Metal-accumulating plants. In: Raskin I, Ensley BD (eds) Phytoremediation of toxic metals: 
using plants to clean up the environment. Wiley, New York, pp 193-229

Reeves RD, Brooks RR, Press JR (1980) Nickel accumulation by species of Peltaria Jacq. (Cruciferae). Taxon 29:629-633

Reeves RD, Baker AJM, Borhidi A, Berazaín R (1996) Nickelaccumulating plants from the ancient serpentine soils of Cuba. New Phytol 133:217-224

Reeves RD, Schwartz C, Morel JL, Edmondson J (2001) Distribution and metal-accumulating behavior of Thlaspi caerulescens and associated metallophytes in France. Int J Phytoremediation 3(2):145-172

Robinson D (1994) Tansley review No. 73. The responses of plants to non-uniform supplies of nutrients. New Phytol 127:635-674

Robinson BH, Leblanc M, Petit D, Brooks RR, Kirkman JH, Gregg PEH (1998) The potential of Thlaspi caerulescens for phytoremediation of contaminated soils. Plant Soil 203: $47-56$

Saison C, Schwartz C, Morel JL (2004) Hyperaccumulation of metals by as affected by root development and $\mathrm{Cd}-\mathrm{Zn} / \mathrm{Ca}-$ $\mathrm{Mg}$ interactions. International Journal of Phytoremediation 6(1):49-61

Salinitro M, van der Ent A, Tognacchini A, Tassoni A (2020) Stress responses and nickel and zinc accumulation in different accessions of Stellaria media (L.) Vill. In response to solution $\mathrm{pH}$ variation in hydroponic culture. Plant Physiol Biochem 148:133-141

Schenk HJ, Callaway RM, Mahall BE (1999) Spatial root segregation: are plants territorial? Adv Ecol Res 28:145-168

Schwartz C, Morel JL, Saumier S, Whiting SN, Baker AJM (1999) Root development of the zinc-hyperaccumulator plant Thlaspi caerulescens as affected by metal origin, content and localization in soil. Plant Soil 208:103-115

Schwartz C, Echevarria G, Morel JL (2003) Phytoextraction of cadmium with Thlaspi caerulescens. Plant Soil 249:27-35

Schwartz C, Sirguey C, Peronny S, Reeves RD, Bourgaud F, Morel JL (2006) Testing of outstanding individuals of Thlaspi caerulescens for $\mathrm{Cd}$ phytoextraction. Int $\mathrm{J}$ Phytoremediation 8:339-357

Shen ZG, Zhao FJ, McGrath SP (1997) Uptake and transport of zinc in the hyperaccumulator Thlaspi caerulescens and the non-hyperaccumulator Thlaspi ochroleucum. Plant Cell Environ 20:898-906

Simon E (1975) La dynamique de la végétation de quelques sites métallifères dans la règion d'Eupen et Aix-la-Chapelle en relation avec les facteurs édaphiques. Bull Soc Roy Bot Belg 108:273-286
Smit AL, George E, Groenwold J (2000) Root observations and measurements at (transparent) interfaces with soil. In: Smit AL, Bengough AG, Engels C, van Noordwijk M, Pellerin S, van de Geijn SC (eds) Root methods. Springer, Berlin, Heidelberg

Sterckeman T, Cazes Y, Gonneau C, Sirguey C (2017) Phenotyping 60 populations of Noccaea caerulescens provides a broader knowledge of variation in traits of interest for phytoextraction. Plant Soil 418(1-2):523-540

van der Ent A, Baker AJM, Reeves RD, Pollard AJ, Schat H (2013) Hyperaccumulators of metal and metalloid trace elements: facts and fiction. Plant Soil 362:319-334

Vàzquez MD, Barcelo J, Poschenrieder C, Madico J, Hatton P, Baker AJM, Cope G (1992) Localization of zinc and cadmium in Thlaspi caerulescens (Brassicaceae), a metallophyte that can hyperaccumulate both metals. J Plant Physiol 140: 350-355

Verbruggen N, Hermans C, Schat H (2009) Molecular mechanisms of metal hyperaccumulation in plants. New Phytol 181:759-776

Verbruggen N, Juraniec M, Baliardini C, Meyer CL (2013) Tolerance to cadmium in plants: the special case of hyperaccumulators. BioMetals 26:633-638

Wenzel WW, Lombi E, Adriano DC (1999) Biogeochemical processes in the rhizosphere: role in phytoremediation of metalpolluted soils. In: Prasad NMV, Hagemeyer J (eds) Heavy metal stress in plants- from molecules to ecosystems. Springer Verlag, Heidelberg, pp 273-303

Wenzel WW, Bunkowsky M, Puschenreiter M, Horak O (2003) Rhizosphere characteristics of indigenously growing nickel hyperaccumulator and excluder plants on serpentine soil. Environ Pollut 123:131-138

Whiting SN, Leake JR, McGrath SP, Baker AJM (2000) Positive responses to zinc and cadmium by roots of the hyperaccumulator Thlaspi caerulescens. New Phytol 145: 199-210

Zhao F, McGrath SP, Crosland AR (1994) Comparison of three wet digestion methods for the determination of plant Sulphur by inductively coupled plasma atomic emission spectroscopy (ICP-AES). Commun Soil Sci Plant Anal 25:407-418

Publisher's note Springer Nature remains neutral with regard to jurisdictional claims in published maps and institutional affiliations. 